\title{
A Sample Activity for Holding a Studio Art - Painting - Course in a Museum
}

\author{
Süreyya Genç, Ferhunde Küçükşen Öner* \\ Faculty of Education, Bartın University, Bartın, Turkey
}

Copyright $\subseteq 2018$ by authors, all rights reserved. Authors agree that this article remains permanently open access under the terms of the Creative Commons Attribution License 4.0 International License

\begin{abstract}
Museums are the most effective settings for life-wide learning used in arts education. The aim of this study is to determine the effect of use of museums for educational purposes on a Studio Art - painting - course. In this study designed according to case studies technique, one of the qualitative research methods, a semi-structured interview form was used to determine students' opinions on the learning process. The study group of the research was composed of sophomore students from the Division of Painting Education of the Department of Fine Arts Education at Bartin University. A museum trip took place in this four-week study, after which students were requested to draw some oil painting. Following the hands-on work, students were interviewed, and their drawings were collected. Data obtained from student interviews were put into a descriptive analysis, and they were arranged according to the specific theme of each. Oil paintings created by students as part of the study were interpreted descriptively by consulting experts, too. The results showed that students were really enjoyed attending a course in a museum, drawing right there. Students stated that they were attracted and got excited by different activities and learning environments in general and by attending a course in the museum, in particular. Considering data obtained from the interviews, the positive contribution reported by students was also reflected on their oil paint drawings, which were the practical component of the study.
\end{abstract}

Keywords Arts Education, Studio Art Course, Learning in Museum, Active Learning, Department of Fine Arts Division of Painting, Students' Opinions

\section{Introduction}

"Those teaching in any branch of art are responsible teaching it in a way that encourages learners to think. should do their job by keeping in mind that mental processing takes part in art as much as handicraft does. "

\section{Joshua REYNOLDS}

In Turkey, Studio Art, Basic Arts Education, and Design courses constitute the backbone of arts education given as part of the Undergraduate Programs of Art Teaching Education. The Studio Art - painting - courses have such objectives as training prospective Visual Arts Teachers on principles of teaching and learning, introducing those prospective teachers to different art techniques and materials, and letting them use these techniques; establishing a high aesthetic sense/pleasure to perceive and evaluate art; providing them with the ability to perceive past artworks and creating new ones by discovering their own skills.

Importance of Studio Art courses reveals itself automatically since this course is given for six hours a week during six semesters of the programs of training art teachers, and according to the new bachelor's degree program updated in 2018 this course is given for five hours a week. During this training process, students not only improve their art skills but also learn methods and techniques that they will use when they become Visual Arts Teachers. In the courses generally composed of the works conducted in workshop, there are also some extra-workshop activities. Exterior space drawings and nature studies, art gallery/museum trips and works made during these trips can be given as examples of these extra-workshop activities. Reinforcing learning by extra-workshop activities can be considered as part of the modern notion of learning by experiencing. In this context, according to Erinç (1994), "Only through an art education given in appropriate time and environment is it possible to uncover aesthetic and artistic concerns of an individual, as well as to make art the lifestyle of the individual. Such kind of training includes two different objectives. First one is an art education given with an aim of producing artists, and the second one is an art education towards educating individuals who can look at the world from various perspectives and who have universal minds. However, only through the help of other educational 
fields related to arts is it possible for an individual to discover himself, and to know about his skills and expectations," [8]

As a pair of extra-workshop activities, museum trips and hands-on work in museum have multi-dimensional benefits in terms of learning and teaching practices. The most effective factor involved in making multi-dimensional benefit out of such type of activity is that the Studio Art course in museum is a lively and meaningful course. Therefore, it is necessary to emphasize the importance of museums and museum trips.

Art production may fall short in terms of creating original works of art regardless of how much study is done within a workshop consisting of four walls. Students of arts must keep their memories, knowledge, experiences, and imaginations vivid to produce art. At this point, "Museum collections provoke imagination. Collections offer a rich source for different experiences thanks to many stories they tell, various knowledge they have, and different thoughts they suggest. Given the fact that any materials can be used to stimulate creative thinking, museum objects can be regarded among the ones having the highest power of stimuli" [5]. Therefore, art studies conducted in museums may carry students to a different dimension of creativity.

Museums can be considered as spaces that show changes and developments occurring within the process by revealing the historical process of human life and art. Vital and artistic memory created by museums paves the way to imagination for those who receive art education and who make art. "By exhibiting artworks in museums, relations between art students and artworks are revealed, and also the habit of expanding and deepening individuals' knowledge and habit of reasoning are taught. Besides, individuals' imagination and feelings are enriched, and their creativity is supported. Through the training given in the form of viewing the original artworks during the education in museums, individuals will have the chance to receive more exciting, effective and permanent training getting rid of the traditional education system"[3]. Thanks to the courses in museum, a more permanent learning and rigorous working environment will be provided: "Museum experience covers various properties such as individualistic, social and physical dimensions, interaction with objects through perceptions and interests, making observations, expressing opinions and emotions, using imagination, making associations with his/her own life, getting informed, seeing and making sense of perspective/message of the museum, reading objects, sharing cultural values and life, seeking out the truth, making practice and evaluations" [4]. Considering and showing museums as part of art education shortens the distance between history, theory and practice for those receiving art education at higher education level, and these approaches allow student to see how abstract ideas are transferred into practice: "Learning in museum setting seems to support learning at school. Teachers at school usually introduce students to subjects that students do not feel with their senses and that they have never experienced. This kind of an introduction away from the level of the students' lives cannot prevent the subjects from remaining abstract. However, what there is in a museum setting is a group of active learners"[1].

Holding Studio Art courses in a museum setting can be said to be an effective way of improving students' art skills. First of all, students who experience a course, which they previously attended in a workshop setting, in a new museum setting begin to involve more effectively in that course by realizing the importance of their training in terms of art history. Strengthening the bond established with the course in museum environment, students act more willing at the point of creating original artworks and improving their artistic skills.

Another important aspect of organizing Studio Art course in a museum is linked with the development of teaching skills. The prospective teachers studying in the undergraduate program of Art Teaching will develop a teaching-centered relationship with museums, which are the places where artistic and historical heritage reside, they will understand the value of museums, and they will be able to grasp that their future students will see art more differently when museum training is combined with art education. It is also important for students receiving this training in the museum to realize that museum and art education is not only related to the field of expertise but also important and meaningful in every stage of human life. For this reason, Studio Art courses given in museums will provide contributions to both their learning and teaching dimensions. In this context, "[7] in a study, comparing having a visual arts course in a museum to the one in a classroom setting, Mercin (2008) found out that students exposed to museum training realized the importance of art, liked the course, and that learning by seeing in museum became effective in establishing students' emotions and thoughts about this course. On the other hand, it was revealed that students who were subjected to teaching in classroom setting got bored with the course, they were not involved in various activities, and there were no changes in students' emotions and thoughts about this course. As a result of the study, it was suggested that visual arts course be supported with museum ambiance outside classroom." (Cited by [2]).

Accordingly, the active learning approach which is already important in every stage of education becomes extremely important both in terms of arts itself and arts education especially for the students and institutions dealing with arts. Therefore, Studio Art courses should be enriched by museum settings where students will actively take part. As specified by [9], there is a need for new methods that will support the already known methods in order to ensure active participation of students, to make learning funnier and different, and to ensure that learning 
will be permanent.

By keeping this point in mind, this study aims to answer the questions of how important a course in a museum setting is, to what extent the artworks in the museums contribute to the students' artistic works, and how applicable such a training is. To answer these questions, the sophomore students of Studio Art course of the undergraduate program of Fine Arts Education at Bartın University were invited to a museum trip, after which they were requested to share their opinions via a semi-structured interview form, and they were requested to draw some oil painting right in the museum.

\section{Materials and Methods}

In this study, case study survey model was used which is one of the qualitative research methods. According to Türengil (1975:78); "case study survey models are arrangements aiming at making a conclusion by determining relationships of a certain unit (individual, family, school, hospital, association etc.) with itself and its surroundings in depth and width in a research universe" (Cited by [6]). "Information collected by such arrangements is only valid for the specific unit analyzed; it does not have a generalization purpose beyond analysis. However, generalizability can be ensured by an increase in number of cases to be studied"[6]. Here, the aim of the study is "to perform analytical generalizations rather than statistical generalizations for a universe, namely, to establish a theory or put theoretical propositions forward. In this sense, there is no fundamental difference technically between experimental and case studies"[10]. In the light of such information, a particular group was examined in depth in this study, and data obtained was interpreted with no concern of generalization.

A semi-structured interview form was used to collect data in the study. Relevant literature was reviewed for the interview form prepared by researchers to obtain in-depth knowledge about the study subject; the basic concepts constituting the objective of this study were determined, expert opinion was taken to ensure validity of the content of the questions, and the form consisting of four open-ended questions was prepared. Student opinions obtained from the interview form were coded in the form of S1, S2, S3,... S12. Findings were interpreted under titles of these themes, and direct quotations were included. The oil paintings that the students drew along the process were analyzed with the help of experts.

\subsection{Study Group}

The study group of the research is composed of 7 female and 5 male students, which makes 12 sophomore students from the Division of Art Education in the Department of Fine Arts Education at Bartın University.

\subsection{Collection and Analysis of the Data}

To obtain research data, a museum trip was organized for the Studio Art course in the fall term of 2017-2018 academic year. After getting necessary permission, Amasra Museum of Archaeology was visited with students. First, general information was given about the museum and museum artworks, then the students were told to draw any artworks they wanted. After the museum visit, each student was asked to draw an oil painting based on the artworks in the museum on a circle canvas $50 \mathrm{~cm}$ in diameter. During the study period, which lasted 4 weeks in total, students completed their oil paintings in Studio Art courses. At the end of the study, the semi-structured interview, which was prepared by the researchers through consulting experts was presented to the students; their opinions about the learning process were taken, and students' artworks were collected.

The data obtained from the student interviews were descriptively analyzed. According to [10]; while it is possible to arrange data according to themes revealed by research questions, they can also be presented by considering questions or dimensions used during interview and observation processes. In descriptive analysis, direct quotes are frequently used to reflect opinions of individuals who are interviewed or observed in a dramatic way. These analyses are interpreted, their cause and effect relationships are examined, and some results are obtained. Another data collection tool of the study, students' works, was interpreted descriptively by consulting experts.

\section{Findings and Discussion}

In this section, some interpretations are made in the light of the findings. These findings are divided into two titles: the findings obtained from the semi-structured interview form and the findings obtained from students' oil paintings that they drew after the museum trip.

\subsection{The Findings Obtained From the Semi-Structured Interview Form}

\subsubsection{Students' Opinions on the Course in Museum}

All students participating in the study stated that there had been a positive contribution of the course taught in museums. Students indicated that they were quite impressed by magical atmosphere of the museum, that it was an interesting experience to have a course in a museum, and that different learning environments were inspiring. It was stated that attending courses in different settings rather than workshop motivated them, attracted the students' attention and they enjoyed that activity. Students expressed their opinions about the course in museum with the following sentences:

"Museum as a setting inspired us. It was a quite pleasant event. Doing different activities makes a positive 
impact in terms of this course. I think the course is productive and entertaining. It allows us to learn by seeing and entertaining, and to have an enjoyable course." (S4)

"It had an extremely positive contribution. It has given us a different experience." (S3)

"I have really enjoyed the course in the museum. Drawing in a museum setting has affected my thoughts on art and my department in a positive direction." (S7)

"We had course in a different environment outside workshop. It was a productive lesson." (S8)

"It was very inspiring, thanks to the freedom and comfort provided, and I felt like drawing more and more. It was better to lecture in a peaceful environment rather than lecturing within four walls." (S10)

"Courses given in different settings affect us positively in terms of morale and motivation. We had a very enjoyable day on the field with my friends. I both made my art and enjoyed myself." (S11)

"It was very enjoyable to learn about the structure of historical monuments and what was done in that period in Amasra Museum." (S12)

In line with the answers given by students, it can be said that the museum visit made along the course had a positive effect on students, the course given in museum setting increased students' interests in this course, aroused a sense of curiosity and students enjoyed it very much. In terms of affecting learning positively, museums are very important learning venues. It can be given as a proof of the effect left by the course given in museum from students' expression of such an effect of this museum trip in a different learning environment.

\subsubsection{Students' Opinions on Drawing in the Museum}

During the museum trip conducted along this study, students found the opportunity to make drawings in the museum. When we examine students' opinions, regarding drawing studies conducted in the museum, all students enjoyed drawing in the museum, and they indicated that this practice contributed positively to their drawings. It was observed that students enjoyed transferring the effect left by artworks exhibited in the museum on canvas together with their excitement they felt. Students emphasized that it was especially a different experience, offered positive contributions from technical perspective, and it affected them very much to make drawing in such an encouraging environment. Some of the students expressed their opinions regarding their drawing studies in the museum as follows:

"To make a detailed analysis by seeing influenced our perceptions positively." (S1)

"There were very beautiful statues. Drawing them on canvas made me very excited." (S3)

"It was a very special experience. Since we were in a more artistic environment, we have learned an enjoyable lesson, which created an utmost inspiration. It had great contribution to our drawings." (S4)

"Since museum had a different atmosphere, it was a pleasant experience for us to make drawing in such an atmosphere." (S5)

"It was very enjoyable to make drawing by examining the marble texture." (S6)

"It was a more encouraging, stimulating and inspiring environment than the school environment. I enjoyed much while drawing." (S7)

"Personally, seeing artworks and working on their sketches allowed us to properly see things such as pattern, color, light etc." (S9)

"I have analyzed my skills on viewing, seeing and reflecting on canvas. I saw light and shade more clearly due to color of the statues." (S10)

It can be seen from answers that learning at museum activities based on learning by doing approach had effects on students. To keep students' interest and attention, it is necessary to include such activities in curricula. It was very exciting for students to work on their sketches while individually analyzing historical artworks that have survived until today, preserved past experiences and remained in museums with their fascinating effects.

\subsubsection{Students' Opinions Regarding What They Felt during Museum Trip and While Drawing}

In answers given by students to the question of what they felt during museum visit and while drawing, it can be seen that they are all thrilled and happy during this process. Students expressed the effect left by artworks in the face of museum's distinctive atmosphere using expressions of amazement. This situation can be sampled with the following statements of the participants:

"I was thrilled to participate in such an event." (S1)

"I am so happy to have such an experience." (S5)

"I am intrigued because it was not such kind of an activity that we normally do." (S7)

"When I first entered the museum, I was thrilled. It was nice to explore the historical monuments." (S8)

"The atmosphere was stunning. Interest of people around was incredibly beautiful. We also obtained information on the history of Amasra. I was quite surprised how people made such beautiful sculptures." (S10)

"I saw what people built in ancient times despite all difficulties. This is emotive." (S11) 
"We were informed about the history of Amasra. I was quite surprised by how people made such beautiful sculptures." (S12)

\subsubsection{Students' Opinions on Their Oil Painting Studies after the Visit to Museum}

Analyzing students' answers, it can be seen that there were no problems experienced during this practice. It was observed that drawing unique oil paintings based on artworks exhibited in the museum after museum trip had a positive effect on students. Students were interested in finding the opportunity to study historical monuments personally and working on any artworks affecting them, and they expressed their satisfaction from this practice. As especially emphasized by some students, it can be seen that students were emotionally affected together with excitement they felt in the museum, and artworks in the museum inspired their oil paintings, guided them technically and ignited students' desire to create artistic works. Students' opinions regarding studies they drew based on artworks in the museum are expressed as follows:

"By seeing the reflection of light on the object, we reflected it on canvas. These sketches helped a lot in my oil painting study. The statues caught my attention a lot, and I wanted to work on a marble statue." (S2)

"For the first time, we studied a historical artifact and worked on its oil painting. I think it was very productive to analyze artworks in detail and work on them." (S3)

"I can say that drawings we made at the museum helped increase our creativity, when we were making oil paintings. It was a different experience. I tried to apply the marble texture." (S5)

"We all sat there like an artist and made our drawings. I felt different on this work that we did personally, and I think I have made a good job by blending my authenticity into my drawing. " (S6)

"While I was walking around the museum, a figure from ancient times attracted my attention, I felt it, and I chose it." (S7)

"It was a pleasure to make oil paintings of the artworks we saw at the museum." (S8)

"It offered us motivation on finding our own style while making our oil paintings, because I used more original brush strokes.” (S9)

"Details and shadow of the picture I drew impressed me much. It had very fine workmanship. I wanted to draw it because I liked the detail in pictures." (S10)

"The most important thing attracted my attention in the museum was a piece located in the section where the old coins were exhibited. When I saw that piece, I envisaged its finished version in my mind." (S11)
Analyzing the answers given by students, it is obvious that most students found some artworks that attracted their attentions even when they were getting information about them, and they visualized their future work on a canvas.

\subsection{Findings Obtained from Students' Oil Paintings}

Percentage-frequency values of artworks that students selected as subjects of their oil painting works are presented in Table 1.

Table 1. Historical artifacts that students selected as subjects for their oil paintings

\begin{tabular}{lll}
\hline Subject & f & \% \\
\hline Sculpture & 4 & 33.3 \\
\hline Coins & 3 & 25 \\
\hline Abacus & 2 & 16.7 \\
\hline Relief & 2 & 16.7 \\
\hline Rock Work & 1 & 8.3 \\
\hline Total & $\mathbf{1 2}$ & $\mathbf{1 0 0}$ \\
\hline
\end{tabular}

Analyzing the Table 1, we can see that many students selected statues as their subjects. Considering also students' answers, we know that the most prominent and exciting historical monuments were the statues. Together with fascinating atmosphere of the museum, unique effect of the statues was also reflected on students' works. Second most selected subject for students' artworks is coin according to Table 1 . These subjects are followed by abacus, relief and stone works respectively. Oil paintings in which students used as a subject for their pictures are given below and interpreted descriptively.
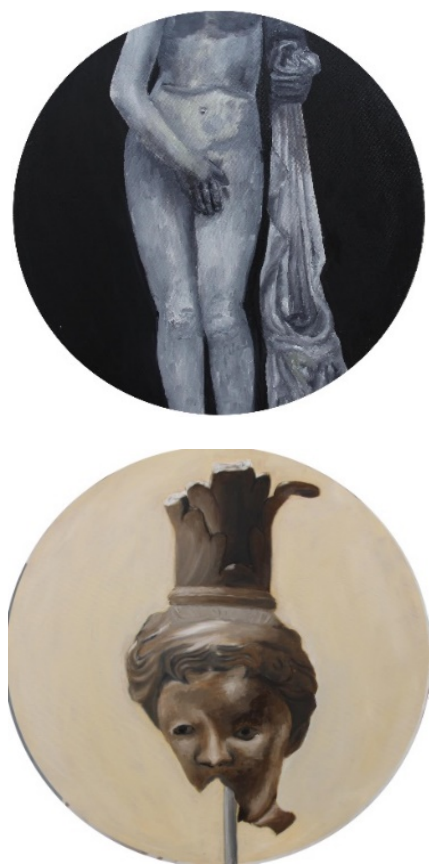


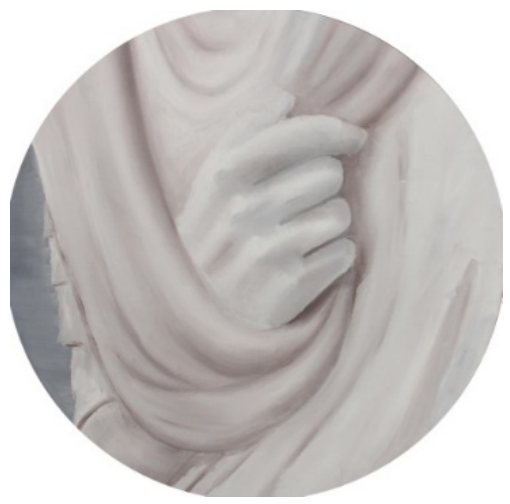

Figure 1. Oil paintings created by students.

In Figure 1, we can see reflections of statues selected by student as subject on their canvas. In the first picture, a certain part of a marble sculpture was drawn. In the study which was placed on canvas in a balanced way, it can be seen that black and white colors are dominant. The picture of the statue placed on a black ground was shaded using gray tones and white color in an attempt to resemble it a marble. In the second picture, the head part of a bronze statue was studied. Unlike the first picture, student here preferred a light background color. To create a bronze-like effect, color preferences were concentrated on brown color and its tones. Shading of the statue head placed in the middle of canvas is very successful. In the third picture, a detailed study was made from a marble statue. In this study, which focuses on the hand of the statue, light colors were dominant. The remarkable point of this study is fabric folds. As we can notice from marble effect in the picture, folds of the fabric were also reflected on the canvas successfully. It can be seen that students, mainly preferring to study a detail of the statue rather than the whole statue, were quite successful on this subject. This is also an indicator of how much students embraced the subject by benefiting from advantages of detail study to achieve their performance and to feel textures of sculptures.

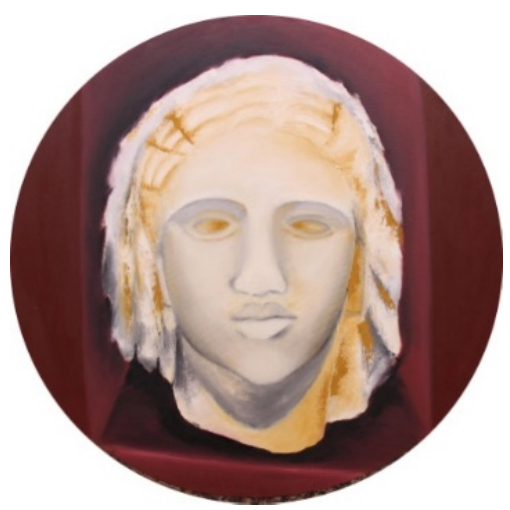

Figure 2. Oil paintings drawn by students.

In Figure 2, which is a bust work of a marble sculpture, the student placed his work in the middle of canvas on a dark color background in claret red color. We see that the student working on a sculpture head used brown and gray tones in shading. To give marble effect and reflection of the light, the students used the color of white and yellow in some works, like the other ones did.
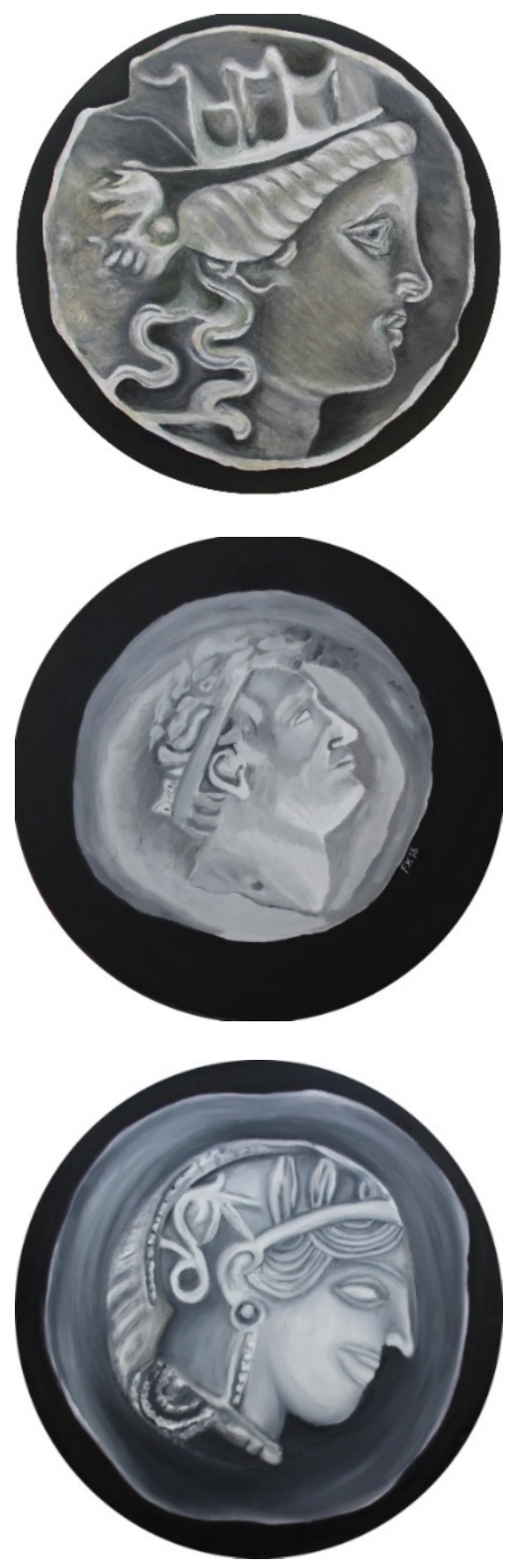

Figure 3. Oil paintings made by students.

In Figure 3, we see works on coins, a subject, which was second mostly selected by students. Students placed pictures of coins made of gold, bronze and silver on their canvases in a balanced way. In the first study, although a little dark green tone can be seen, all the works have black and white color as dominant colors. In particular, details are remarkable on these coin pictures placed on a dark background. Rather than giving the effect of the historical material, students emphasized form and details of these historical artifacts. We can infer from students' works that they established a distinctive style using light and shade, and tones of gray and white colors. 


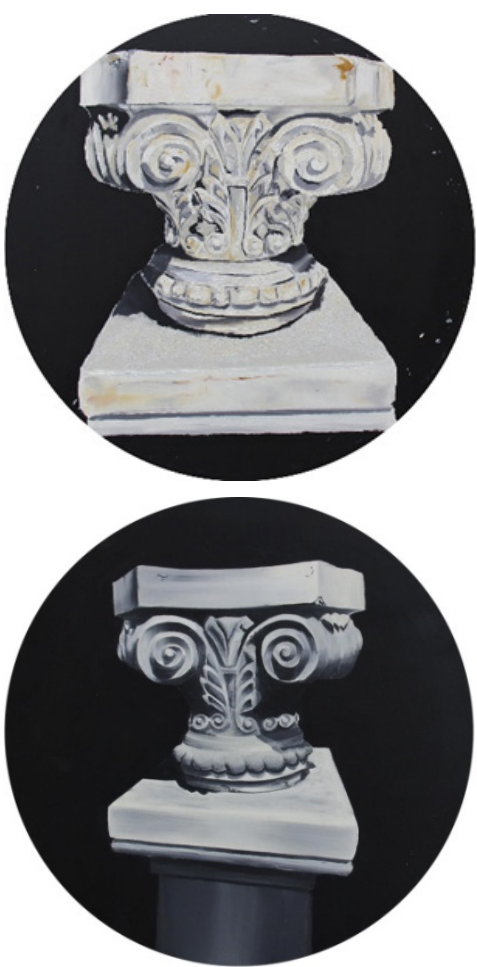

Figure 4. Oil paintings created by students.

When we look at students' works on column heads in the Figure 4, fine workmanship is remarkable at first sight. Light-shade and three-dimension effect on these white-colored column heads placed on a black background were reflected on canvas quite successfully. Marble effect can be felt on these pictures, and in the first picture, we can also see the effect of an artwork extracted under the soil.

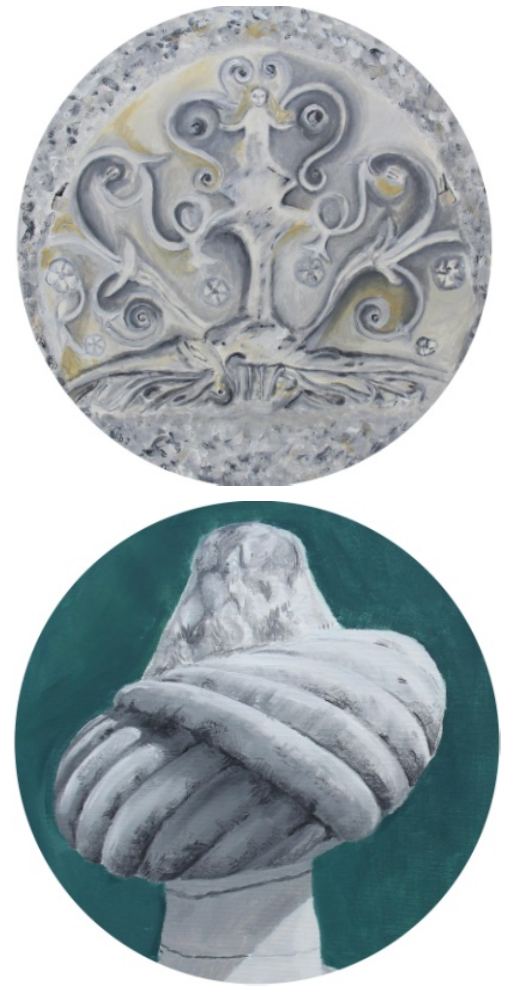

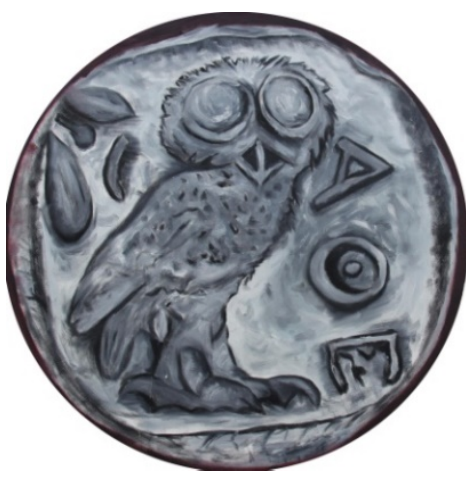

Figure 5.Oil paintings drawn by students

In Figure 5, the first two pictures are oil paintings of stone relief artworks. The artwork seen in the third picture is tombstone. It is possible to see that white and gray tones are dominant also in the third picture. The first picture among those drawn based on relief works was created in a more linear way, and the second one was made in a more dotted way. Stone works placed on a green ground were tried to be depicted by using light-shadow of the work and tones of gray and white colors. While there is a two-dimension perception in studies on relief works, we could perceive three-dimension effect in studies on stone artworks.

\section{Discussion, Conclusions, and Recommendations}

It is inferred from the study that the students' opinions on the museum trip carried out along the Studio Art course and their oil paintings made based on artworks exhibited in the museum are in a positive direction. The facts that the students had enough acquisition at the end of the study, that they associated historical artworks with their perceptions and senses, and that it has been achieved that students' developed their artistic ability are positive sides of this study. Following the museum visit, students were asked to draw oil paintings based on the artworks exhibited in the museum. Taking advantage of facilities and different perspectives offered by museums at every stage and in each course is important in terms of creating an effective learning environment. It can be clearly seen that this hands-on work attracted attention of students, made them excited, aroused their desire towards art, and it was observed that students enjoyed the course. Raising an awareness of museum in a proper way becomes more important in teacher training institutions considering that students will be teachers after graduation. It is one of the significant objectives of education to train individuals who protect cultural heritage, who have historical consciousness, who have awareness of protecting art and historical monuments, and who are environmentally-conscious. In line with this objective, museum trips should be arranged in every level of 
education to teach national awareness in a better way, and students should be allowed to improve themselves in every aspect.

Since museum trips affected the students' opinions positively in terms of interest in and desire towards courses carried out in museum, it should be ensured that every student lives this experience. Not only theoretical courses but also practice-based courses should be also included in different learning environments. As part of the study, the common point of students' opinions on the activity they carried out in artistic sense based on artworks in the museum is that this activity was inspiring. Enriching lesson plans by means of active participation of students in learning process by moving out of the workshop setting, allowing students to learn by doing and student-centered activities are important in terms of effective learning and educating qualified individuals.

According to the results obtained, students achieved an artistic development in their oil paintings prepared based on artworks exhibited in the museum along the Studio Art course, they managed to express themselves in pictorial sense, and they created their drawings with enthusiasm and willingness during artistic creation process. This situation is of importance regarding the objective of the course and the intended behavior. Preparing individual for the life and ensuring that the individual's skills and creativity are revealed can only be possible through successful management of courses. Practice-based courses in art education are basic courses in which students can freely express themselves, realize and develop their abilities and acquire personal and social skills. Keeping students' interests alive and ensuring students learn by doing are significant in terms of achieving objectives of the course. This study in particular is important in that it is an example of workshop courses that are practice-based.

It is advisable to carry out this study in different workshop courses, like ceramics, sculpture, graphics which are practice-based, in order to see whether it creates the same effect or not. Studies, which can be performed on similar subjects using experimental research methods, can be carried out to see the effects of such practices on students' academic achievement, ability of problem solving, behaviors and attitudes.

\section{REFERENCES}

[1] Adıgüzel, H. Ö. Müze Pedagojisinin Türkiye'deki Yansımaları ve Müzelerdeki Yaratıcı Drama Uygulamaları, Müzecilikte Yeni Yaklaşımlar Küreselleşme ve Yerelleşme, Turkish Association of Economic and Social History, Numune Printing, Ankara, 130-143, 2000.

[2] Bolat Aydoğan, K. E. Görsel Sanatlar Öğretmen Adaylarının Görüşleri Bağlamında Müze Eğitimi ve Uygulamaları Dersi, Anadolu Journal of Educational Sciences International, Vol.7, No.5, 72-106, 2017. (http://www.ajesi.dergi.anadolu .edu.tr/yonetim/icerik/makaleler/134-published.pdf)

[3] Buyurgan, S., Mercin, L. Görsel Sanatlar Eğitiminde Müze Eğitimi ve Uygulamaları, V. Özsoy, Görsel Sanatlar Eğitimi Derneği Publications, Ankara, 2005.

[4] Dizdar Terwiel, C. Sanat Eğitiminde Bir Yöntem Olarak Müzelerden Yararlanma, Prof. Dr. İ. San, Eğitim ve Müze Semineri, Kök Publishing, Ankara, 147-153, 2008.

[5] Gartenhaus, A. R., Yaratıcı Düşünme ve Müzeler, (translated: Ruhiser Mergenci, Bekir Onur), Ankara University Publishing, Ankara, 2000.

[6] Karasar, N. Bilimsel Araştırma Yöntemi, Nobel Publishing, Ankara, 2008.

[7] Mercin, L. Görsel Sanatlar Dersinin Müze ve Sinıf Ortamında İşlenişine İlişskin Öğrenci Görüşlerinin Değerlendirilmesi, Elektronik Sosyal Bilimler Dergisi, Vol.7, No: 21, 325-336, 2008. (http://dergipark.gov.tr/dow nload/article-file/70033)

[8] Öztütüncü, S. Disiplinlerarası Atölye Dersleri Üzerine Bir Değerlendirme, Akdeniz Sanat Dergisi, Vol.9, No:19, 15-28,2016.(http://dergipark.gov.tr/download/article-file/27 5532)

[9] Turanlı, S. Oyuna Dayalı Müze Etkinliklerinin Öğrenci Erişi ve Görsel Sanatlar Dersine Karşı Tutumları Üzerine Etkisi/The Effect of Museum Activities Based on Games to The Student Achievement and Their Attitude Towards Art Classes, Unpublished PhD Thesis, Gazi University Institute of Educational Sciences, Ankara, 2012. (https://tez.yok.gov.tr/UlusalTezMerkezi/tezSorguSonucYe ni.jsp)

[10] [Yıldırım, A., Şimsek, H. Sosyal Bilimlerde Nitel AraştırmaYöntemleri, Seçkin Publishing, Ankara, 2002 